\title{
Antioxidant Activity Evaluation in a Series of Heterocyclic Compounds Derived from 1,8-Diaminonaphthalene
}

\author{
Tuo Nanou Tiéba ${ }^{1}$, Kangah Niameke Jean Baptiste ${ }^{1}$, Ballo Daouda ${ }^{2,3}$, \\ Kablan Ahmont Landry Claude ${ }^{4}$, Kodjo Charles Guillaume1, Yapo Ossey Bernard ${ }^{5,6}$, \\ Ziao Nahossé 1
}

${ }^{1}$ Laboratoire de Thermodynamique et de Physico-Chimie du Milieu, UFR SFA, Université NanguiAbrogoua, Abidjan, Côte d'Ivoire

${ }^{2}$ Laboratoire de Chimie Organique Heterocyclique URAC 21, Pôle de Compétence Pharmacochimie, Faculté des Sciences, Université' Mohammed V, Rabat, Moroc

${ }^{3}$ Laboratoire de Constitution et Réaction de la Matière (LCRM), UFR Sciences des Structures de la Matière et Technologie, Université Félix Houphouët-Boigny, Abidjan, Côte d'Ivoire

${ }^{4}$ UFR Des Sciences Biologiques, Université Péléforo Gon Coulibaly de Korhogo, Korhogo, Côte d'Ivoire

${ }^{5}$ Laboratoire Centrale de l'Environnement (LCE), Centre Ivoirien Antipollution (CIAPOL), Abidjan, Côte d'Ivoire

${ }^{6}$ Laboratoire des Sciences de l'Environnement (LSE), UFR SGE, Université Nangui Abrogoua, Abidjan, Côte d'Ivoire

Email: nanoutuo07@gmail.com

How to cite this paper: Tiéba, T.N., Baptiste, K.N.J., Daouda, B., Claude, K.A.L., Guillaume, K.C., Bernard, Y.O. and Nahossé, Z. (2021) Antioxidant Activity Evaluation in a Series of Heterocyclic Compounds Derived from 1,8-Diaminonaphthalene. Journal of Biophysical Chemistry, 12, 1-9.

https://doi.org/10.4236/jbpc.2021.121001

Received: January 11, 2021

Accepted: February 6, 2021

Published: February 9, 2021

Copyright $\odot 2021$ by author(s) and Scientific Research Publishing Inc. This work is licensed under the Creative Commons Attribution International License (CC BY 4.0).

http://creativecommons.org/licenses/by/4.0/

\begin{abstract}
From (2,3-dihydro-1 $H$-perimidin-2-yl)-phenyl, the substitution of $\mathrm{OH}$ group in ortho or para position on the phenyl ring, allows us to synthesize the studied compounds. These three compounds have been characterized by conventional spectroscopic methods (NMR and MS). The interest of this work is to review the antioxidant activity of our compounds. The antioxidant activity screening carried out according to FRAP and DPPH methods revealed significant anti-free radical properties for compounds 1 and 2 even at low concentrations. In contrast to the compound 2, compound 3 for which the $\mathrm{OH}$ group is substituted in para position has the lowest activity in both cases. Therefore the para position seems to be the least sensitive position to increase the antioxidant activity of this pharmacophore.
\end{abstract}

\section{Keywords}

Perimidine, Spectrometry, Antioxidant Activity,

2,2-Diphenyl-1-Picrylhydrazyl Method and Ferric Reducing

Antioxidant Power Method 


\section{Introduction}

The notion of oxidative stress reflects an imbalance between the production of free radicals and the capacity of antioxidant defense mechanisms to detoxify reactive intermediates to repair the resulting damage. This notion was used for the first time by Sies [1]. Studies have shown that oxidative stress is involved in many diseases as a trigger or associated with complications of their course. It is recognized by many that oxidative stress is the cause of diseases such as cancer, cataracts, acute respiratory distress syndrome, pulmonary edema [2], diabetes, Alzheimer's disease, Parkinson's disease, rheumatism, cardiovascular disease [3], infectious diseases such as AIDS [4] [5], syphilis [6], renal failure [7] [8], malaria and gastric ulcers [9] [10] etc. Taking into account the harmful effects of oxidative stress, the scientific community is looking for new, more effective antioxidant molecules.

2,3-dihydro-1H-perimidine, are the products resulting from the condensation of primary amines with carbonyl compounds. In addition to their diverse biological activities [11], and their potential to act as antioxidant [12], antimicrobial, antiulcer, antifungal and antitumor agents [13] [14], this products can be a source of molecules with best antioxidant powers. In this work we are interested in structure-activity relationship in a series of 2,3-dihydro- $1 \mathrm{H}$-perimidine derived from 1,8-diaminonaphthalene presented in Table 1.

\section{Material and Methods}

\subsection{Material}

Benzaldehyde, salicylaldehyde, 4-Hydroxybenzaldehyde, and

benzene-1,8-diaminonaphtalène were procured from Aldrich and used without further purification. All organic solvents were purchased from Merck and dried before use. Melting points were determined in capillary tube using an MPD Mitamura Riken Kogyo (Japan) electrothermal melting point apparatus and are uncorrected. The 1H NMR spectra were recorded on a Bruker-Avance-300 spectrometer, operating at $300 \mathrm{MHz}$. The mass spectra were recorded on a TOF LCT Premier (WATERS) Spectrometer coupled to an HPLC Alliance 2695 chain.

Table 1. Structures of 2,3-dihydro-1H-perimidinesynthesized.

compound




\subsection{Methods}

\subsubsection{Synthesis of 2-Phenyl-2,3-Dihydro-1H-Perimidine}

Benzaldehyde $(19.60 \mathrm{mmol})$ and 1,8-diaminonaphtalène $(9.79 \mathrm{mmol})$ were dissolved in ethanol $(50 \mathrm{ml})$. The mixture was heated at reflux for 07 hours to give a green precipitate. The precipitate obtained was filtered and rinsed in ethanol (Rf: 0.87 in hexane/acetate d'ethyle (2;1), yield: $\left.82 \%, \mathrm{mp}: 206^{\circ} \mathrm{C}\right)$.

\subsubsection{Synthesis of 2-(2,3-Dihydro-1H-Perimidin-2-yl)Phenol}

Salicylaldehyde $(18.80 \mathrm{mmol})$ and 1,8-diaminonaphtalène $(9.35 \mathrm{mmol})$ were dissolved in ether $(30 \mathrm{ml})$. The mixture was stirred at room temperature for three days to give a brown precipitate. The precipitate obtained was filtered and rinsed in ether (Rf: 0.70 in hexane/acetate d'ethyle (2;1) yield: $26.97 \%, \mathrm{mp}$ : $\left.198.2^{\circ} \mathrm{C}\right)$.

\subsubsection{Synthesis of 4-(2,3-Dihydro-1H-Perimidin-2-yl)Phenol}

4-Hydroxybenzaldehyde $(12.61 \mathrm{mmol})$ and 1,8-diaminonaphtalène $(6.32 \mathrm{mmol})$ were dissolved in ethanol $(50 \mathrm{ml})$. The mixture was heated at reflux for 05 hours to give amaroonprecipitate. The precipitate obtained was filtered and rinsed in ethanol (Rf: 0.61 in hexane/acetate d'ethyle $(2 ; 1)$, yield: $47.78 \%, \mathrm{mp}>268^{\circ} \mathrm{C}$ ).

The general synthesis of the four compounds is shown in Figure 1.

\subsubsection{Radical scavening Test}

\section{1) DPPH (2,2-diphenyl-1-picrylhydrazyl) assay}

2,2-diphenyl-1-picrylhydrazyl(DPPH) was one of the first free radicals used to study structure-antioxidant activity relationship of phenolic compounds [15] [16].

\section{Principle}

Reduction of the free radical DPPH by an antioxidant can be followed by UV-Visible spectrometry, by measuring the decrease in absorbance at $517 \mathrm{~nm}$ caused by the antioxidants [17]. In the presence of free radical traps, purple-colored DPPH was reduced to yellow 2,2-diphenyl-1-picrylhydrazine [18].

\section{**Dosage}

DPPH radical trapping activity was measured according to the protocol described by Lopes-Lutz et al. [19] and Athamena et al. [20] $100 \mu \mathrm{L}$ of each methanolic solution of the pure compound at different concentrations $(0.0625-1$ $\mathrm{mg} / \mathrm{mL})$ were added to $2.5 \mathrm{~mL}$ of the methanolicsolution of DPPH $(0.025 \mathrm{~g} / \mathrm{l})$. In

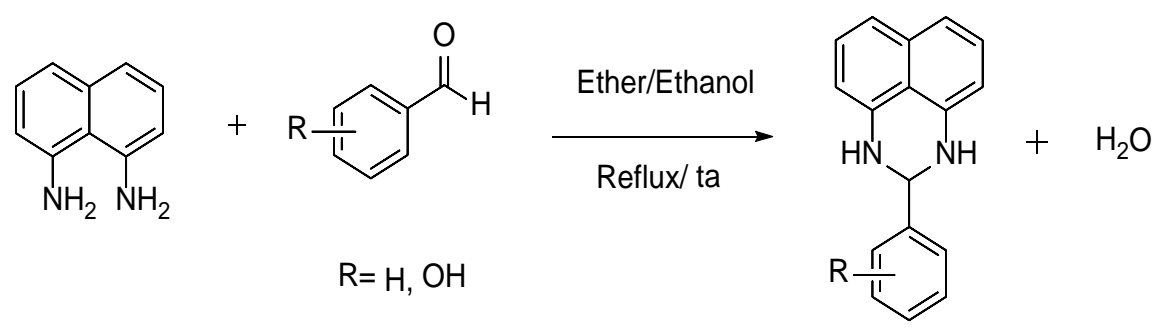

Figure 1. The general synthesis route of compounds 1-3. 
parallel, a negative control was prepared by mixing $100 \mu$ of methanol with 2.5 $\mathrm{ml}$ of the methanolic solution of DPPH. Absorbance reading was made against a blank prepared for each concentration at $517 \mathrm{~nm}$ after 30 minutes of incubation in the dark and at room temperature. The positive control was represented by a solution of a standard antioxidant ascorbic acid, whose absorbance was measured under the same conditions as the samples and for each concentration [21].

The results were expressed in inhibition percentages (I\%) of free radical using the following formula.

$$
\mathrm{I} \%=[(\text { Abs of con neg }- \text { Abs sample }) / \text { Abs of con neg }] \times 100
$$

I\%: Percentage of DPPH inhibition.

Abs Sample: Absorbance of the sample.

Abs of con neg: Absorbance of negative control.

\section{2) FRAP (Ferric Reducing Antioxidant Power) assay}

\section{**Principle}

The process was based on the reduction of a triazine tripyridyl ferric complex to ferrous iron in the presence of antioxidants (test sample). In fact, the sample turns to the blue color followed by colorimetric assay at $593 \mathrm{~nm}$ in the presence of antioxidant. The reagent will be prepared as follows.

\section{**Dosage}

The protocol was based on the method of Benzie et al. [22], which had undergone some modifications by Pulido et al. [23]. A freshly prepared FRAP solution composed of.

- $25 \mathrm{ml}$ of $300 \mathrm{mM}$ acetate buffer.

- $2.5 \mathrm{ml}$ of $10 \mathrm{mM}$ TPTZ solution in $40 \mathrm{mM}$ HClsolution.

- $2.5 \mathrm{ml}$ of a solution of iron chloride at $20 \mathrm{mM}$.

The mixture was incubated at $37^{\circ} \mathrm{C}$ for the duration of the experiment. The test consisted of mixing in glass hemolysis tubes $100 \mu \mathrm{l}$ of extract diluted with $300 \mu \mathrm{l}$ of distilled water and then with $3000 \mu \mathrm{l}$ of working solution maintained at $37^{\circ} \mathrm{C}$. The absorbance was measured at $593 \mathrm{~nm}$ after incubating the reaction in a water bath thermostated at $37^{\circ} \mathrm{C}$ in the dark for exactly 30 minutes. The calibration line was derived from the absorbance read for the trolox solution range ( 0.0312 to $1 \mathrm{mg} / \mathrm{mL}$ ) used as antioxidant reference. The concentration in $\mathrm{mg} / \mathrm{mL}$ of trolox equivalent per gram of dry matter was calculated based on the regression line of the trolox sampling curve.

\section{Results and Discussion}

\subsection{MS Study}

The mass spectra (HR-ESI-MS) of the title compounds showed peaks corresponding to the molecular ions at $\mathrm{m} / \mathrm{z} 263[\mathrm{M}+\mathrm{H}]^{+}$, that allowed to propose $\mathrm{C}_{17} \mathrm{H}_{14} \mathrm{~N}_{2}$ empirical formula for compounds 2 and 3. Concerning compounds 1 the peak at $\mathrm{m} / \mathrm{z} 247[\mathrm{M}+\mathrm{H}]^{+}$, was conform to propose $\mathrm{C}_{17} \mathrm{H}_{14} \mathrm{~N}_{2}$ empirical formula. 


\section{2. ${ }^{1} \mathrm{H}$ NMR and ${ }^{13} \mathrm{C}$ NMR Spectroscopy}

${ }^{1} \mathrm{H}$ NMR and ${ }^{13} \mathrm{C}$ NMR spectral data in deuterated $\mathrm{CDCl} 3$ solution of the synthesized compounds are given in Table 2. The resonance of protons had been assigned on the basis of their integration and multiplicity pattern [24]. The ${ }^{1} \mathrm{H}$ NMR spectra exhibited multi-signals at $3.51 ; 3.50 ; 3.36 \mathrm{ppm}$ respectively for compounds 1, 2 and 3, attributed to protons was bonded to azote atoms $\mathrm{CH}-\mathrm{N}-$. The singulet at $5.80 ; 5.75 ; 5.29 \mathrm{ppm}$ for compounds 1,2 and 3 , attributed to perimidine cyclic protons $\mathrm{CH}-$, respectively. The multi-signals within the $8.19-6.47$ ppm range are assigned to the aromatic protons of the three rings.

The signals at $60.97 ; 61.46 ; 76.6 \mathrm{ppm}$ attributed to carbon are bonded both to two azote atoms and to phenyl group.

The 1H-NMR spectral data of the perimidines synthesized were in accord with the proposed structures.

\subsection{Anti-Radical Activity by DPPH Method}

Statistical analysis in this study gave the results recorded in Table 3. Analysis of Table 3 showed that all the compounds studied had antioxidant properties. We also observed a significant difference $(\mathrm{P}<0.001)$ between inhibition percentages when switching from one compound to another. Inhibition percentage determination indicated $89,212 \pm 0.462 ; 87,687 \pm 1019 ; 73,574 \pm 3025 ; 43,598 \pm 7743$, respectively for Trolox, compounds 2,1 and 3 . Like FRAP method, DPPH assays showed that the antioxidant activities were ranked one more time in Trolox $>$ $2>1>3$ decreasing order. For molecules 1 and 3, we obtained relatively lower inhibition values than Trolox, but with a non-negligible inhibition effect.

Table 2. ${ }^{1} \mathrm{H}$ NMR data ${ }^{\mathrm{a}-\mathrm{c}}$ and ${ }^{13} \mathrm{C}$ NMR data of compounds.

\begin{tabular}{cccccc}
\hline compounds & $\begin{array}{c}\text { Molecular } \\
\text { formula }\end{array}$ & $\begin{array}{c}\mathrm{N}-\mathrm{H} \\
\mathrm{m}\end{array}$ & $\begin{array}{c}\mathrm{C}-\mathrm{H} \\
\mathrm{s}\end{array}$ & $\begin{array}{c}\mathrm{C}_{6}-\mathrm{H} \\
\mathrm{m}\end{array}$ & $\mathrm{N}-\mathrm{C}-\mathrm{H}$ \\
\hline 1 & $\mathrm{C}_{17} \mathrm{H}_{14} \mathrm{~N}_{2}$ & $3.51(2 \mathrm{H})$ & $5.80(1 \mathrm{H})$ & $8.08-6.47(11 \mathrm{H})$ & 60.97 \\
2 & $\mathrm{C}_{17} \mathrm{H}_{14} \mathrm{~N}_{2} \mathrm{O}$ & $3.50(2 \mathrm{H})$ & $5.75(1 \mathrm{H})$ & $8.24-6.48(10 \mathrm{H})$ & 61.46 \\
\hline & $\mathrm{C}_{17} \mathrm{H}_{14} \mathrm{~N}_{2} \mathrm{O}$ & $3.36(2 \mathrm{H})$ & $5.29(1 \mathrm{H})$ & $8.19-6.64(10 \mathrm{H})$ & 76.6 \\
\hline
\end{tabular}

${ }^{\mathrm{a}}$ Multiplicity is given as $\mathrm{s}=$ singlet, $\mathrm{m}=$ multi-signals; ${ }^{\mathrm{b}} \mathrm{Chemical}$ shits in ppm; ${ }^{\mathrm{c}}$ Integration: number of protons in brackets.

Table 3. Inhibition percentage values by DPPH method.

\begin{tabular}{cc}
\hline Compounds & Means of inhibition \% + standard deviation \\
\hline 3 & $43.598 \pm 7.743$ \\
2 & $73.574 \pm 3.025$ \\
1 & $87.687 \pm 1.019$ \\
TROLOX & $89.212 \pm 0.462$ \\
F & 167.602 \\
P & $<0.001$ \\
\hline
\end{tabular}


Statistically, compound 2 had the same antiradical effect as Trolox. Compound 3 was the one that weakest inhibited DPPH even at low concentrations, as shown by the histogram below (Figure 2).

The histogram revealed in detail the antioxidant power of this series of compounds. In the concentration range localized between 1 and $0.0312 \mathrm{mg} / \mathrm{ml}$, the inhibition percentage values of compound 2 are comparable to Trolox one. At $0.5 \mathrm{mg} / \mathrm{ml}$, compound 2 showed an antiradical activity greater than the reference molecule. whatever the concentration, 2,3-dihydro-1H-perimidine compound, substitued by the hydroxyde group in para position on benzylic nuclei seem to be unfavorable to improve the biological activity. Whereas, ortho position appeared to be the site most sensitive to increase the antioxidant activity of this pharmacophore. For this class of molecule, it is the first time, to our knowledge, that, such important antioxidant properties were observed.

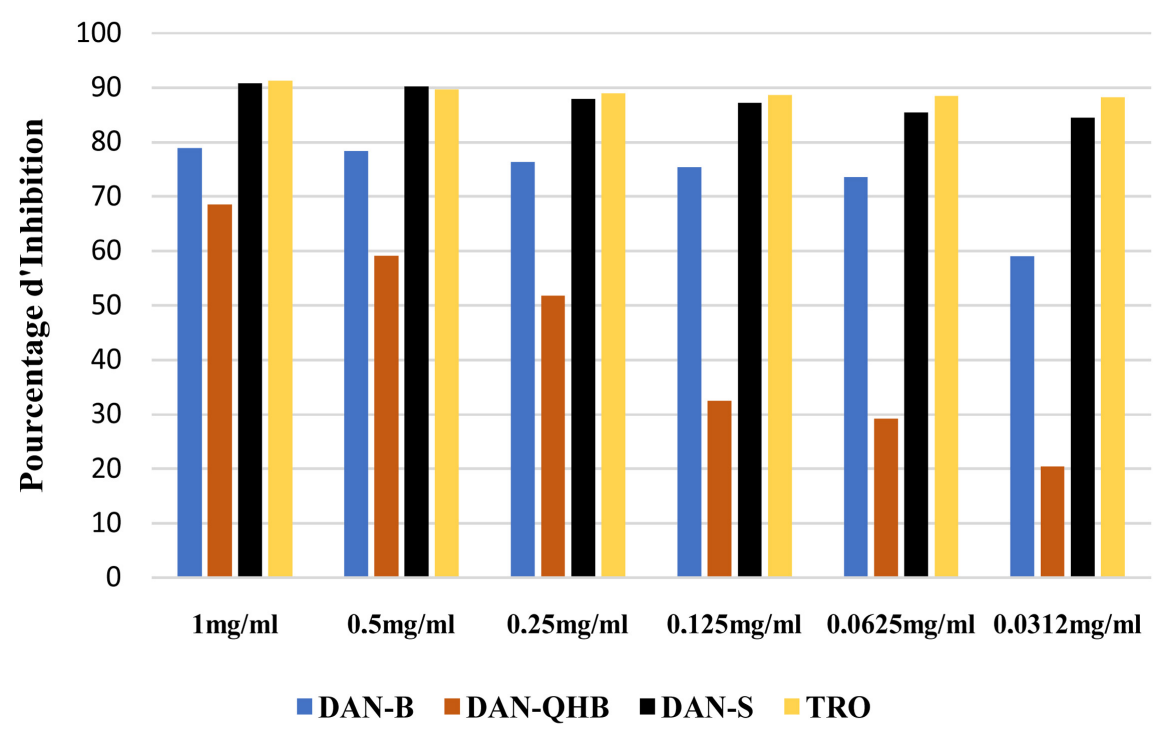

Figure 2. Antioxidant activity by DPPH method at 1 to $0.0312 \mathrm{mg} / \mathrm{mL}$.

\subsection{Ferric Reducing Antioxidant Power (FRAP) Assay}

The results of the ferric reduction antioxidant power, expressed in $\mathrm{mg} / \mathrm{mL}$ Trolox equivalent, obtained from a calibration straight line at different concentrations, are presented in Table 4.

Table 4. Antioxidant power of ferric reduction of pure compounds.

\begin{tabular}{cc}
\hline Compounds & Means of inhibition \% + standard deviation \\
\hline 3 & $0.07946658 \pm 0.03925419$ \\
1 & $0.09285675 \pm 0.04448092$ \\
2 & $0.09700133 \pm 0.04513959$ \\
Fisher value F & 20.618 \\
P value & $<0.001$ \\
\hline
\end{tabular}


According to FRAP method, in this series, antioxidant activities are ranked in as follow decreasing order: $1>2>3$.

These results revealed that the compounds 1 and 2 with FRAP values respectively of $0.09700133 \pm 0.04513959$ and $0.09285675 \pm 0.04448092$, are the most active compared to compound $3(\mathrm{P}<0.001)$. It is deduced that the no-substituted compound 1 is the very most active of them. Compound 3 with its FRAP value of $0.07946658 \pm 0.03925419$ is the least active of them. The compound 3 meanwhile, has mean antioxidant activity. From the compound 1, introduction of a hydroxide group in this structure sensibly decreased the antioxidant activity. Therefore, para position on the benzylidene nuclei seemed to be the least sensitive position which is not promotes biological activity.

\section{Conclusion}

Antioxidant screening carried out according to FRAP and DPPH methods revealed important antiradical properties for compounds 1 and 2 . This study also revealed that the antioxidant activities were arranged in decreasing order: $2>1>$ 3 for DPPH and $1>2>3$ for FRAP. Ortho-substituted compound 2 in the case of DPPH and no-substituted in FRAP case are the most active, exhibited a much higher antioxidant activity even at low concentrations. With their excellent antioxidant activity, compounds 2 and 1 are proven to become good candidate for the development of a new class of 2,3-dihydro-1H-perimidine profile antioxidant compounds.

\section{Conflicts of Interest}

The authors declare no conflicts of interest regarding the publication of this paper.

\section{References}

[1] Sies, H. (1985) Oxidative Stress: Introductory Remarks. In: Sies, H., Ed., Oxidative Stress, Academic Press, London, 1-8. https://doi.org/10.1016/B978-0-12-642760-8.50005-3

[2] Bartosz, G. (2003) Generation of Reactive Oxygen Species in Biological Systems. Comments on Toxicology, 9, 5-21. https://doi.org/10.1080/08865140302420

[3] Montagnier, L., Olivier, R. and Pasquier, C. (1997) Oxidative Stress in Cancer, AIDS and Neurodegenerative Diseases. CRC Press, Boca Raton, 546. https://doi.org/10.1201/9781482292213

[4] Smietana, M., Clayette, P., Mialocq, P., Vasseur, J.-J. and Oiry, J. (2008) Synthesis of new $N$-isobutyryl-L-cysteine/MEA Conjugates: Evaluation of Their Free RadicalScavenging, Activities and Anti-HIV Properties in Human Macrophages. Bioorganic Chemistry, 36, 133-140. https://doi.org/10.1016/j.bioorg.2008.02.001

[5] Velázquez, I., Plaud, M., Wojna, V., Skolasky, R., Laspiur, J.P. and Meléndez, L.M. (2009) Antioxidant Enzyme Dysfunction in Monocytes and CSF of Hispanic Women with HIV Associated Cognitive Impairment. Journal of Neuroimmunology, 206, 106111. https://doi.org/10.1016/j.jneuroim.2008.10.013

[6] Hebert-Schuster, M., Borderie, D., Grange, P.A., Lemarechal, H., Kavian, N., Bat- 
teux, F. and Dupin, N. (2011) Syphilis, Stress Oxydant et Statut Antioxydant. Annales de Dermatologie et de Vénéréologie, 138, A251-A252. https://doi.org/10.1016/j.annder.2011.10.304

[7] Rodrigo, R. and Bosco, C. (2006) Oxidative Stress and Protective Effects of Polyphenols: Comparative Studies in Human and Rodent Kidney. A Review. Comparative Biochemistry and Physiology Part C: Toxicology \& Pharmacology, 142, 317-327. https://doi.org/10.1016/j.cbpc.2005.11.002

[8] Montazerifar, F., Hashemi, M., Karajibani, M. and Dikshit, M. (2010) Natural Antioxidants and Oxidative Stress Markers in Hemodialysis Patients. Hong Kong Journal of Nephrology, 12, 57-61. https://doi.org/10.1016/S1561-5413(10)60013-0

[9] Nanda, N.K. and Das, B.S. (2000) Presence of Pro-Oxidants in Plasma of Patients Suffering from Falciparum Malaria. Transactions of the Royal Society of Tropical Medicine and Hygiene, 94, 684-688. https://doi.org/10.1016/S0035-9203(00)90233-5

[10] Gülçin, I.V., Mshvildadze, A. and Gepdiremen, R. (2006) Screening of Antiradical and Antioxidant Activity of Monodesmosides and Crude Extract from Leontice smirnowii Tuber. Phytomedicine, 13, 343-351.

https://doi.org/10.1016/j.phymed.2005.03.009

[11] Dzieduszycka, M., Martelli, S., Arciemiuk, M., Bontemps-Gracz, M.M., Kupiec, A. and Borowski, E. (2002) Effect of Modification of 6-[(Aminoalkyl)amino]-7Hbenzo[e]-perimidin-7-ones on Their Cytotoxic Activity Toward Sensitive and Multidrug Resistant Tumor Cell Lines. Synthesis and Biological Evaluation. Bioorganic \& Medicinal Chemistry, 10, 1025-1035. https://doi.org/10.1016/S0968-0896(01)00358-3

[12] Blois, M.S. (1958) Antioxidant Determinations by the Use of a Stable Free Radical. Nature, 181, 1199-1200. https://doi.org/10.1038/1811199a0

[13] Bu, X., Deady, L.W., Finlay, G.J., Baguley, B.C. and Denny, W.A.J. (2001) Synthesis and Cytotoxic Activity of 7-Oxo-7 $\mathrm{H}$-dibenz $[f, i j]$ isoquinoline and 7-Oxo-7 $\mathrm{H}$-benzo [e]perimidine Derivatives. Journal of Medicinal Chemistry, 44, 2004-2014. https://doi.org/10.1021/jm0100411

[14] Starshikoy, N.M. and Pozharskii, F.T. (1975) Synthesis of 2-(5-halogeno-2-f uryl)2,3-dihydroperimidines. Chemistry of Heterocyclic Compounds, 9, 922-924. https://doi.org/10.1007/BF00471584

[15] Padmanabhan, P. and Jangle, S.N. (2012) Evaluation of DPPH Radical Scavenging Activity and Reducing Power of Four Selected Medicinal Plants and Their Combinations. International Journal of Pharmaceutical Sciencesand Drug Research, 4, 143-146.

[16] Popovici, C., Saykova, I. and Tylkowsk, B. (2009) Evaluation de l'activité antioxydant des composés phénoliques par la réactivité avec le radical libre DPPH. Revue de Génie Industriel, 4, 25-39.

[17] Molyneux, P. and Songklanakarin, J. (2004) The Use of the Stable Free Radical Diphenylpicrylhydrazyl (DPPH) for Estimating Antioxidant Activity. Sciences Technology, 26, 211-219.

[18] Maataoui, B.S., Myene, A. and Hilali, S. (2006) Activités antiradicalaires d'extraits de jus de fruits du figuier de barbarie (Opuntia ficus indica). Lebanese Science Journal, 7, 3-8.

[19] Lopes-Lutz, D., Alviano, C., Alviano, P. and Kolodziejczyk, P. (2008) Screening of Chemical Composition, Antimicrobial and Antioxidant Activities of Artemisia Essential Oils. Phytochemistry, 69, 1732-1738.

https://doi.org/10.1016/j.phytochem.2008.02.014 
[20] Athamena, S., Chalghem, I., Kassah-Laouar, A., Laroui, S. and Khebri, S. (2010) Activiteanti-Oxydante et antimicrobienne d'extraits de Cuminum cyminum L. Lebanese Science Journal, 11, 69-81.

[21] Bougandoura, N. and Bendimerad, N. (2013) Evaluation de l'activité antioxydante des extraits aqueux et méthanolique de Saturejacalamintha ssp. nepeta(L.) Briq. Nature \&Technologie, 9, 14-19.

[22] Benzie, I.F. and Strain, J.J. (1996) The Ferric Reducing Ability of Plasma (FRAP) as a Measure of "Antioxidant Power": The FRAP Assay. Analytical Biochemistry, 239, 70-76. https://doi.org/10.1006/abio.1996.0292

[23] Sanchez-Pulido, L., Diffley, J.F.X. and Ponting, C.P. (2010) Homology explains the functional similarities of Treslin/Ticrr and Sld3. Current Biology, 20, R509-R510. https://doi.org/10.1016/j.cub.2010.05.021

[24] Silverstein, R.M., Webster, F.X. and Kiemle, D.J. (2016) Identification Spectrométrique de composés Organiques. 3e éd, De Boeck Supérieur, Louvain-la-Neuve, 145-150. 